第 5 回水質自動制御計測国際ワークショップよりœん横浜セッションキーノートレポート〉

\title{
ICA in the UK water industry: The state of the art (1)
}

\author{
Prof. Ronald BRIGGS *
}

【概要】この論文は, 英国の水処理分野における計 装, 制御ならびに自動化（ＩＣＡ）の発展の過程を述 べたものである．また，最近の法令に関する事項，特 に1989年におこなわれた10の地域水処理組合（Regional Water Authority）の民営化，および，同時に設 立された全国河川組合 (National River Authority： NR A）の与えた影響，ならびに1992年から施行され るEC（ヨーロッパ共同体）としての規制が与えると 思われる影響等についても, 詳細に述べている. 一方, センサーならびに周辺機器の開発状況や, 水処理シス テムの制御におけるコンピュータによるエキスパート システムの進展状況についてあ解説し，さらに，河川 水質ならびに水・廃水処理設備等の遠隔監視のための 遠隔測定システムについても詳しく述べている.

【キーワード】I C A，法令，遠隔測定，センサー， エキスパートシステム。

\section{はじめに}

最近の英国の水処理分野では, 多くの処理プラント の運転に，以前にも増して計装システムを用いること の必要性が強調されている。これは，処理プラントの 運転効率を向上させることにより，より高い経済効果 を目指すむのであるが，この傾向は，水処理産業界が198 9年に民営化されて以来一層強くなっている，また， より正確なプロセス制御の必要性ならびに無人プラン トの遠隔監視の必要性が増大したのみではなく，全国 河川組合の設置に伴い，処理水質ならびに河川水質を モニタリングするための, 設置型, ポータブル型，あ るいは場合によっては, 水没型などの信頼性の高い計 装機器に対する必要性も増大している。

全体として見た場合, I C A 機器の性能, 中でもフ ロントエンドのセンサーの性能は, 多くの適用例, 特

* Measurement and Instrumentation Centre

City university, London
に水処理分野での適用例において，満足できるものと は見なされてこなかった．このような問題の原因の一 端は，機器側の技術的な欠陥にもあるが，一方では， これらの機器を使用し，また保守する人間の側にも問 題がある，さらに，ユーザー側の望む仕様を機器製造 業界に反映させることのできる機構が欠けていたこと あ，ユーザー側が不満を訴える主な原因のひとつであっ たことも明らかになってきた．

これを受けて水処理産業界全体は, DOE／NWC の水処理分野における制御システムに関する作業部会 の提出したレポート（DOE／NWC 1981）に示さ れた勧告の実現化に続き, 水処理研究センター（Water Research Centre：WR C）を中心として，必要な 仕様の決定，ならびに 2 力所の中心的な評価・実証施 設 (Evaluation and Demonstration Facilities: E D F S ）の設立および活用を図るために多大な資金 ならび努力を傾注してるところである。これらの分野 における，現在までの進展状況に関する詳細について は，報文（Elvidge 1989）を参照されたい，また，W RCならびにその他の機関により, 水処理産業界なら びに水を利用する分野の人々が必要としていることの 把握，およびセンサーやシステム技術の最近の発展状 況の調查にも努力が払われている（Briggs and Grat$\tan 1990$ ).

\section{水処理産業界ならびに関連産業界のニーズ}

\section{(a) 測定すべき項目}

測定すべき項目については，環境局（the Department of Environment）ならびに Welsh Office の 共同文書（1982）に詳しく述べられている，なお，本 文書は人が消費するための水質に関する EC の指導書 （80／778／E E C）を参照したあので，ECの指導書 を引用するとともに, イングランドならびにウェール ズ地方に指導書の内容をどのようにして実現するべき 
かのガイドラインを示したものである. 本文書では, 必要な要素項目を, 以下の 4 つに分類している.

一官 能 項 目 (Organoleptic)

一物理化学的項目 (Physiochemical)

一毒 性 物 質 (Toxic substances)

一微生物学的項目 (Microbiological)

それぞれの目標值達成の証明は，多くの場合，計画 的なサンプリングとそれに続く実験室での分析によっ てなされるが，現在では参照法による分析をおこなう ための機器が多数存在しているように思われる。しか し, 水処理組合の化学者の大半は, 将来的には, 特に 毒性物質の分析法に関してさらに検出限界を低くする （検出感度を高くする）ことが必要になると予想して いる，また, 例えば溶存酸素, 硝酸性窒素, アンモ二 ア性窒素などの微生物学的な項目など, 要素項目によっ ては現場で測定する方が望ましい場合もある。さらに， 場合によっては吸水口などにおける連続モニタリング が必要とされることああり，これは頑丈で信頼性の高 い計装機器ならびに遠隔測定装置がなければ，現場常 駐の作業員が必要であることを意味している。

(b) 運転上のニーズ

水処理組合, 電力供給事業体などの公益事業体など の国の機関は，その大半が環境保全のために改良・改 善の努力を継続して払うことをポリシーとしているが, これはとりあなおさずより優れたプロセス制御が必要 とされ, 結局, 信頼性の高いプロセス制御機器に対す る要求が高くなっていくことを示唆している。

上記の意味で最む重要な指標を, 優先順位によって 並べたリストは，プロセスのための計装の仕様と評価 グループ (Process Instrumentation Specification and Evaluation Group : P I S EG）によって作 成されている。 また，水処理組合協会（Association of Water Authorities) の I C A ポリシーグループ ならびにそのエンジニア等の成果は, WRCによりユー ザーの必要とする仕様の作成に活かされてきた．しか し，施行が間近に迫っているE C の規則のため，表 1 に示すようにこのリストは健康に影響を及ばす可能性 があると思われる重金属および微量有機物質を含むよ うに拡張されている.

\section{(c) 計装機器ならびにシステムの必要性}

現代では，既存あるいは開発中の遠隔測定システム とのインターフェイスが可能な，完全な計装システム （場合によっては, バッテリーによる操作が可能なポー タブル型システム）が必要であることは明かである．
表 1 最む重要な水質等の指標（拡張版）

\begin{tabular}{|c|c|c|c|}
\hline $\begin{array}{l}\text { 水処理及 } \\
\text { び配水 }\end{array}$ & 下水处理 & 污泥処分 & $\begin{array}{l}\text { 水源及び処理 } \\
\text { 水の放流水域 }\end{array}$ \\
\hline $\begin{array}{c}\text { 残留塩素 } \\
\text { 色度 } \\
\text { 濁度 } \\
\text { 有機 物 } \\
\mathrm{pH} \\
\text { オゾン } \\
\text { アル } \\
\text { 鉄 } \\
\text { マンガン }\end{array}$ & 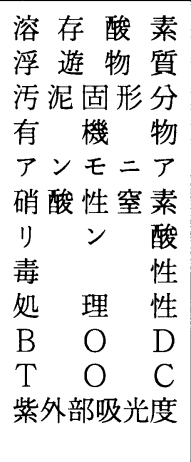 & $\begin{array}{l}\text { 重金属 } \\
\text { 病原菌 }\end{array}$ & 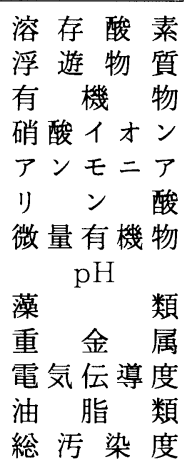 \\
\hline
\end{tabular}

各欄の指標は, 優先度順に表示.

これらのシステムは，以下の要素から構成されていな ければならない。

(i) 大半の適用例において, 試料の前調整ユニット，

(ii) 頑丈で，信頼性が高く，かつ比較的廉価なセンサー システム

(iii) センサーならびに試料の前調整ユニットの操作お よびコントロールの可能な, マイクロプロセッサーを用 いた電子システムで，さらにその他の制御信号の出力や， アラームシステム，あるいは他の遠隔測定システムへの データの出力が可能なユニット（例えば， R S 232等）。

河川管理者のための, バッテリー駆動型ポータブル システムに関する仕様は，最近NRAによって制定さ れている.また，このようなポータブルシステムは， 特に英国では水源の約 $30 \%$ を低地を流れる河川から得 ているため，取水水質を管理するためにも非常に有効 だと思われる，なお，英国におけるその他の主要な上 水水源は，地下水および眝水池であるが，これらの水 源に比べると，低地を流れる河川は，水源として比較 的安価に利用できるむのの，より污染を受けやすい水 源であると言える。

主要取水口の約半数は, ショートサーキッティング がないものとして 1 日から10日間の滞留時間に相当す る容積の貯水施設を堤防脇に有している。しかし，残 りの取水口には一切の貯水施設は設けられていず，取 水された水は通常約 4 時間で浄水設備を経て配水シス テムに送られる。したがって，低濃度の有害金属，油 分およびその他の炭化水素, 殺虫剤, 除草剤, ならび にその他の発ガン物質等を十分に高感度で検出できる， 信頼性の高いセンサーが必要とされていると思われる。 


\section{センサーのロジスティックス}

工業廃水，家庭廃水，あるいは様々なプロセスから 排出される処理水にセンサーを長期間用いる場合，そ のセンサーの性能や信頼性が劣化することを避けるこ とはできない．これは，機器にとってより好ましい環 境である実験室において，同種あるいは似通った指標 の測定に用いられている機器を基に開発されたセンサー の場合に特に顕著である。このようなセンサーは，天 候に対する考慮が十分に払われていないような設置環 境においては，センサー部に污れや生物膜，あるいはス ライム層が発生しやすく，また熟練者による管理が得に くい状況にあるため，往々にして信頼性が欠けてしまう． このような状況への対策には様々なものがあるが， これらは一般的に計装のための経費ならびにシステム の複雑さを増大してしまう傾向がある，対策法の一つ として二重センサーシステムを挙げることができるが, このシステムは, 元々最大限の信頼性が要求される浄 水システムへの取水水質を保護するために開発された あのである (Briggs 1981).このシステムでは同一 のセンサーを二つ用い，一方は取水される水中に設置 され，他方のセンサーは，微生物の繁殖を防ぐ薬剤を 混入した校正溶液中でスタンドバイの状態で保持され ている.

このシステムでは，ある一定の期間毎の定期的な二 つのセンサーの置き換え，ならびに，片方のセンサー の測定値がそれまでの傾向から著しく異なって示され た場合の二つのセンサーの置き換えを自動的におこな うことにより, 試料水質の急な変化とセンサーの故障 を共に検出することができるものである．

\section{センサー技術の最近の発達}

環境中やプロセスにおける流体の状態のモニタリン グには, 非接触型のセンサー, あるいは, 光ファイバー を用いたセンサーのように，本質的に安全な設計のな されている装置が必要である場合が多い.

しかし，例えばある種の水質の測定，あるいは，発 醉，薬品および医学的な分野において必要である処理 性や毒性といった項目，および，栄養素，基質，重金 属ならびに微量有機物などの濃度を測定するための非 接触型のセンサーは，まだ実用化されているとは言え ない，これらの分野において，最新の半導体テクノロ ジーに基づいた安価な種々のセンサーの開発の正否が 大きな影響を与えることは明らかである。 (a) 特定の污染物質をモニタリングするためのセンサー 以下に, 半導体センサーおよび電気光学テクノロジー に基づいた測定システムの概要について述べる。これ らのシステムは，原則的には製造ならびに設置が低コ

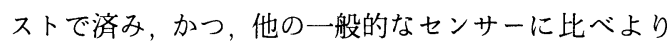
効果的であり，また応用範囲の広いものである.

\section{半導体センサー}

現在最す魅力的に思える可能性の一つは, 重金属イ オン濃度や微量有機物濃度を測定するために,これら に敏感に反応する物質を金属酸化物半導体型電界効果 トランジスター（MOSFETs）のゲートの列の上に 付着させたものを，マイクロプロセッサーと一体化し て一つのチップとしたあのである.このセンサーシス テムの利点は，十分大きな市場があれば大量生産によ る低コスト化が可能なこと，小型化できること，多重 センサーシステム化が容易なこと，したがって信頼性 の向上が図れ，場合によっては現場における洗浄，校 正も可能であることなどである。なお，単に比率測定 で目的の達成が充分可能な場合，このような半導体セ ンサーは特に有効なシステムである。

重金属濃度測定センサー開発の好例に, ハーロウの スタンダードテレフォン研究所 (Standard Telephone Laboratories at Harlow）が研究開発の先駆者之 なった技術がある。これは，MOSFET のゲートの列 の上に，金属酸化物を含む可溶性リン酸ガラスまたは ホウ酸ガラス，あるいはその両方を付着させたすので, 半導体イオン選択電極の列を構成した形になっている. このゲートの中の一つを，指標としては余り重要でな くかつ保存性のあるイオンに対して感度を有するよう にすれば, このゲートの出力との比として他のゲート の出力を測定することができ, 外部比較電極が不要と なる.さらに，相対的な濃度の変化傾向のみが必要で ある場合，試料中の対照イオンの活量を一定に保持す る必要むなくなり, 各ゲートの電位とイオン活量の関 係を現すネルンスト型の連立方程式を解くためのマイ クロプロセッサーと MOSFET のゲートの列を一体 化したセンサーを用いることによって，多種類のイオ ンを同時に測定することが可能となる。このようなセ ンサーの実現化には, 各ゲートが特定のイオンに対し てのみ高い感度を示す必要があることは明かである． これまでの研究結果によれば, 鈶, 銅, 水銀, カド ウム, 覀鉛, ならびに, 鉄, そして, 恐らくアルミニゥム とマンガン，については，この方法で濃度を測定でき そうである，ただし，感度が充分に高いとは言えない 
場合あある。

他の研究開発の例としては, カルコゲナイドガラス を用いたもので, 元々は医療分野における, $\mathrm{pH}$ ，ナ トリウム，カリウムならびに塩素の測定に適用するた めに研究開発が始められたものである。このタイプの センサーの研究開発は, エジンバラ大学 (Edinburgh University) のオーエン (Owen), ニューキャッス ル・アポン・タイン大学 (University of Newcastleupon-Tyne) のコビングトンおよびドブソン (Covington, Dobson）等によって始められたあのである. このテクノロジーは基本的には上に記した方法と同じ であり,ゲート上に付着される感度物質が違うという 点で異なっているだけである。この例で開発研究当初 から解決されなければならなかった最大の問題はゲー トに付着される感度物質の選択ではなく, MOSFET 全体の防水であった，酸化珪素の代わりに窒化珪素を 基盤の材料として用いることによりこの問題はある程 度改善されたが，実際に要求されるような長期間に渡 る安定性を達成するためには依然シールの問題が解決 されなければならない。

微量有機物の測定のため酵素を MOSFET のゲー 卜上へ固定化する技術に関する研究開発は，ケース・ ウェストン大学 (Case Weston University) ならび にアルター（Ultar）において始められている。また, これに関連する技術の研究開発も英国内の数多くの研 究所等でおこなわれているが，その中であ特にンーン・ EM I 社 (Thorn-EMI) の中央研究所 (Central Research Laboratories), UMIST，およびインペ リアル大学 (Imperial College) 等が中心となって いる.

酵素を利用するあう一つの技術の研究開発について は，モスバックおよびダニエルソンによって述べられ ている (Mosbach \& Danielson, 1981). 彼らの方 法は酵素をサーミスター上に固定するすのであるが， サーミスター以外にも集積回路の一部を反応熱を感度 よく測定できるように構成することができるはずであ り，上に述べたものと同様な一体化構造をとることが 可能である. したがって，このテクノロジーによって あ，多重センサーシステムとデータプロセッシングユ ニットを一体化したプローブを作成することが可能で ある.

\section{光学的な測定手法}

電気光学的な手法と光ファイバー技術をマイクロプ ロセッサーと組み合わせて利用することは，水処理産
業界における多くの問題の解決法として有望視されて いるが，これは抜本的な安全性への配慮が重視されな ければならない危険区域における水質等の測定，ある いは，危険区域から信号の伝達が必要な場合等に特に 適した技術と考えられる.さらに, 複数の光ファイバー /光学センサーシステムをパターン認識技術と組み合 わせたシステムは, プラント全体や機器の状態をモ二 タリングするのに特に有効である。これらの技術に関 する詳細はブリッグスとグラッタンの論文を参照され たい (Briggs \& Grattan 1990).

光学センサーを端的に表現すれば, 赤外線, 可視光 線，あるいは紫外線の発光を利用し，測定対象とする 変数の変化を検出するものと言うことができる.なお， この場合, 発光現象之測定対象の間によ゙のような種類 の相互関係があるかは問わない，現在は測定の容易さ 等の理由から光ファイバーのセンサーへの応用に重点 が置かれているが, 放散された光線の “外気中 (Openair)”すなわち自由空間内での伝播む同様に重要な問 題である. また, いわゆるハイブリッド型の機器や， 光学的に電力が供給される構造の電気的センサーの例 に見られるように，場合によっては測定対象とセンサー 間の 1 次相互作用が光学的な相互作用である必要は必 ずしむない，しかし，この場合センサーからの信号は， 信号変換により光学的な信号として出力されなければ ならない。

外因的な（Extrinsic）ファイバーセンサーでは， ファイバーは主に光源からの光を測定部位に導くため に用いられ，測定部位において測定対象との相互作用 によって生じる偏光, 波長の変化, 相の変化あるいは 強度の変化は信号の変換をおこなう受光部で検出され る.この範疇に属するシステムには, 複数の信号を少 しずつずれた短い時間間隔でサンプリングし一度に送 信するタイプの多重送信式センサー（time-division multiplexed sensor), 光線符号化式センサー（shaftencoded sensor)，および，異なった波長帯を用いて 複数の信号を同時に送信するタイプの多重送信式セン サー ( "frequency-out" sensor, frequency-division multiplexed sensor) 等のシステム例を挙げる ことができるが、これらはいずれる光線の強度には依 存しない方式の信号伝達系である。一方，内因的な (Intrinsic) ファイバーセンサーでは，ファイバー内 の光線の伝播が検出可能な形で錯乱を受けることによっ てファイバー自体がセンサーとして機能する。このた め, 分散型および準分散型のセンサーシステムは, こ 
の範疇のセンサーとして特に重要なあのである，後者 の範瞦に属するセンサーを化学的な变数の測定に適用 した例はまだ非常に限られており，現在，研究ならび に開発が進められている最中である。

物理的，あるいは化学的な指標を測定することに利 用できる光学的な現象は数多く存在している.この分 野における課題の多くについての研究は世界中で進め られているが，その中には光ファイバーを用いた，信 頼性が高く，かつ設置ならびに保守の容易なデー夕通 信システムとしての利用法も含まれている. 光ファイ
バーテクノロジーの利点ならびに適用の可能性は，以 下のようにまとめることができる，すなわち，本質的 に, 電気的に安全であり，また，電磁気的なノイズに 無縁であること,さらに光ファイバーは軽量，小型で あり，また，多くの場合，混信あおこらない，壊れや すい現在のレーザーや電球に代わる強力な半導体レー ザーや検出器の開発にとむない, コストの低減ならび にコンパクト化への大いなる可能性が存在している. (次号へつづく)

\section{第19回 日本水質污濁研究協会セミナーのご案内}

「水質予測モデルの基礎と実際」

主催 : (社)水質污濁研究協会

水質予測に関する調查・研究の分野では, コンピュー 夕の普及とともにモデルの開発が盛んに行われてき ました，近年，湖沼水質保全特別措置法が制定され， これに伴う湖沼水質保全計画が策定される等, 水質

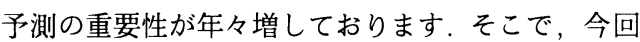
は，水質予測に初めて取り組もうとしている方々並 びに現場実務者を対象に，水質予測モデルの作成と コンピュータを用いた計算手法，予測値と実測值と の検証と評価並びにモデルの現場への適用方法等に ついて理解を得ることを目的に，平易でわかりやす いセミナーを企画いたしました. 多数の皆様の御参 加をお待ちしております。

期

場 所 : 北とぴあ（東京都北区王子 1-11-1） (TEL 03-5390-1100)

参 加 費: 会員15,000円，非会員25,000円

申 込 先：(社日本水質污濁研究協会 セミナー係 \%160 東京都新宿区本塩町12番地 四谷ニューマンション307号 TEL 03-3351-2272

申込み方法 : 八ガキに(1)参加者氏名，(2)会員・非会 員の別（公益会員または賛助会員の場 合は団体名または会社名を添記)，(3)連 絡先（住所および電話番号）をご記入 のうえ，お申込み下さい。
プログラム

第1日目（8月20日(炏)

$9: 30 \sim 9: 40$ 開会挨拶

$9: 40 \sim 10: 30$ 湖沼水質保全計画の見直の方向 性について

環境庁水質保全局水質管理課

$10: 30 \sim 12: 00$ 水質予測手法の概論(1)

一水理モデルによる水質予测 の意義と限界一

東京農工大 岡田光正

12:00 13：00 休 息

$13: 00 \sim 14: 00$ 水質予測手法の概論 $(2)$

一水質予測の手順之利用例 東京農工大 岡田光正

14:00 14:10 休 息

14: 10〜17:00 パソコンをもちいた簡単な生態 系モデルの構築

琵琶湖研究所 大西行雄

第 2 日（8 月21日(水)

$9: 30 \sim 12: 30$ 拡散モデルの河川，沿岸海域へ の適用事例

日本データーサービス㑣）三船修司

$12: 30 \sim 13: 30$ 休 息

$13: 30 \sim 16: 30$ 有限要素法による流体解析の 基礎

中央大学理工学部 川原睦人

$16: 30 \sim 16: 40$ 閉会挨拶 